\title{
Reliability-based analysis of Lázaro Cárdenas breakwater including the economical impact of the port activity
}

\author{
David De Leon ${ }^{\text {a }}$ Lourdes Loza ${ }^{\text {a }}$ \\ ${ }^{a}$ Facultad de Ingeniería, Universidad Autónoma del Estado de México,Toluca, Estado de México, México, Calle Cerro de \\ Coatepec, Paseo Universidad s/n, Universitaria, 50130, Toluca de Lerdo, México
}

\begin{abstract}
Breakwaters are important infrastructure intended to prevent disasters on the coastline, especially if they are planned to protect some port facilities whose operation is essential for the regional and national economy. Breakwaters design must consider the randomness of the hydrometeorological hazards that may occur at the port site. Given the imperfection of the predictive models, also an epistemic uncertainty has to be included into the design process. In this paper, a formulation to assess the impact that the epistemic uncertainty in the predicted mean wave height has over the breakwater reliability, is proposed and illustrated for an important port in México.

The formulation identifies confidence intervals for the breakwater reliability providing a quantitative basis for conservative decisions by taking into account specific percentiles of the reliability index as an improvement of the traditional consideration of the mean value. Also, target values of the breakwater reliability are calculated from the condition of minimum expected life-cycle cost. In addition, a curve of the breakwater initial cost vs. reliability is proposed, as a practical tool towards the optimal decision making on design and maintenance to prevent disasters. Reliability calculations are performed via FORM (First Order Reliability Methods) approximation and MCS (Monte Carlo simulations techniques) and the cost of consequences include potential fatalities and the economic loss of maritime and port activities.
\end{abstract}

Keywords: Breakwater reliability, aleatory uncertainties, epistemic uncertainties, FORM approximation, target reliability, optimal design/maintenance, Monte Carlo Simulation.

\section{Introduction}

The Kahului Harbor breakwaters in Maui, Hawaii, have suffered damages due to several storms since 1943 and their cross sections have been modified with a total cost of several million US dollars (Sargent et al., 1988). In 1960 a rubble-mound outer breakwater in Crescent City Harbor, California was extensively damaged during a severe storm (Magoon et al., 1974). Sines breakwater in Portugal was destroyed by two storms in 1978, and The Arzew El Djedid breakwater, in Algeria, was severely damaged by another storm in 1980 (Burcharth, 1987). 
During the Great East Japan earthquake, in 2011, several breakwaters were damaged or destroyed due to tsunamis that occurred after as a consequence of an earthquake (Mimura et al., 2011).

Risk is always present as a consequence of the uncertain occurrence of hazards, like natural hazards, structures vulnerability and the consequences of damages or failure on the structures (Ang, 1984). The quantification of risk is important to prevent or mitigate disasters and the implementation of riskbased criteria contributes on that purpose. Uncertainties on the demand prediction and the models used to represent performance, need to be considered as random variables. Given that aleatory uncertainties come from the inherent variability of the random variable and cannot be reduced, only the epistemic (which comes from the imperfection of analytical tools, limitations of data or sampling, etc.) is the one that may be reduced up to some extent (Ang et al., 2005). Actually, the value of information theory provides basis to get cost/benefit ratios to invest on new information whose cost are offset by the benefits, or expected gains, derived from the reduction on epistemic uncertainty (Volpe National Transportation Systems Center, 1998). Bayesian techniques have been applied since de 60's to update models and information that improves the predictions as new information is incorporated to calibrate the analytical representations (Esteva, 1969).

Breakwaters are a part of a large infrastructure chain designed to provide protection to the entrance to ports, and to offer a probability that the ship operations are under convenient safety bounds for the port normal performance and the projected generation of income.

The design of breakwaters has been largely based on the work by Hudson (1959) who set the criteria to resist the instability of the core elements. The early work of Van de Kreeke et al. (1964), opened the way to develop optimal design guidelines for breakwaters. And the probabilistic analysis started to be considered as an alternative to the deterministic design of breakwaters (Van der Meer, 1988a, 1988b).

Structural reliability methods have been applied, for example, by Sorensen, et al. (1994) and the use of simplified approaches, like when a complex system is idealized as a series system, has been proposed (Christiani et al., 1996).

The U.S. Army Corps of Engineers (1977) performed studies about the reliability of breakwaters based on stability and damage indicators (Melby et al., 1997). Also, the PIANC (Permanent International Commission for the Navigation Congresses, which is a world association focused on waterborne transportation), developed some technical guidelines (MarCom WG 196, 2016). In the past, several probabilistic design tools were proposed (Oumeraci et al., 1999). The use of reliabilitybased partial safety factors procedures have been explored (Castillo et al., 2004), and the calculation of the target failure probability was also presented (Nagao et al., 2005). However, a specific treatment 
of aleatory and epistemic uncertainties, with its advantages, has not been included for breakwaters, so far.

De Leon-Escobedo and Fuentes-Mariles, 2008), the effect of having an imperfect knowledge on the wave height, over the breakwater reliability was assessed. However, the only random variable was the wave height and the only method considered was FOSM.

Modern techniques, as the use of saddle points to identify the failure point, have been applied to perform the uncertainty analysis of engineering systems by the mean value first order approximation (Xiao et al., 2012).

As one of the modern artificial intelligence techniques, the theory of fuzzy random variables has served to perform the reliability-based risk analysis of a rubble-mound breakwater, by applying Monte Carlo Simulation (MCS) techniques with fuzzy variables (Koç et al., 2013).

Probability interval hybrid uncertainty analysis has been studied for complex structures having aleatory and epistemic uncertainties and it was found that a triple-loop nested analysis may be required for optimal design problems (Jiang et al., 2018)

By introducing epistemic uncertainty on the mean wave height, makes the reliability index to become a random variable. And, by performing MCS, the histogram of the reliability index may be built. For engineering decision, an appropriate reliability level may then be selected in terms of percentiles or confidence levels; for example, for some risk-aversive operators, the percentiles 80, 90 or 99 may be adequate. The formulation may be implemented to design, assessment, inspection, maintenance or retrofit of breakwaters. Depending on the degree of conservatism desired, a proper option may be selected. This provides additional room for conservative decisions, as compared to the conventional use of the mean value of the reliability index. This approach appears to be tuned up with the trend of modern risk management philosophies (Ang et al., 2005).

In the future, this kind of procedure may be used to get optimal maintenance schedules or to generate recommendations to extend the lifetime of breakwaters approaching its end management plans considered by owners and operators.

On the other hand, the importance of commercial ports for the economy of a country requires a special care of the owners and the government, because all the facilities belonging to them are exposed to the latent risk because of the uncertainty of the hidrometeorological events. Breakwater play an essential role in the activities that take place in the port, since when they are damaged the ships cannot carry out the loading and unloading activities in the corresponding port terminals, as above mentioned. 
This document contains a methodology as a tool to the decision makers determine the maintenance schedules or to generate recommendations to extend the lifetime of breakwaters and to avoid the break of normal activities in maritime ports, especially in commercial ports. The first section contains an introduction and some of the concepts used to easy understand of the document. Section two shows the methodology developed to evaluate the breakwater reliability, and the impact that the epistemic uncertainty (on the predicted mean wave height) has over the breakwater reliability; this is done by using FOSM approximation and MCS techniques. Also, the target failure probability is obtained in order to have an acceptable value for design. In section three, the methodology is applied to the Lázaro Cárdenas port, in México, taking into account its specific industrial characteristics of it and the high impact of this port in the Mexican economy. Also, the the comparison between the breakwater failure probability and its target value is discussed. Section fourth encloses the analysis of results. Finally, fith section contains conclusions and recommendation of the work.

\section{Methodology: Breakwater reliability analysis}

The methodology proposed is integrated by three steps: i. The First Order Second Moments approximation (FOSM) is implemented for the breakwater, ii. MCS techniques are applied to get the reliability index $\beta$ for each trial with epistemic uncertainty, iii. The expected life-cycle cost is calculated based on the reliability index calculated and, witht the corresponding failure probability, commercial expected losses are calculated.

The first order second moments approach has the advantage of being easy to implement on the basis of the limit state function and the first two statistical moments of the involved variables. If the limit state is a linear function, the approximation produces exact results but, as the function becomes nonlinear, the method losses approximation. Besides, the failure point is approximated by the mean values of the variables. For the specific case of the stability of armour breakwaters is difficult to know, a priori, if the results provided by FOSM have a reasonable approximation. In order to compare these results with a method which is not based on the linear approximation, MCS techniques are applied. These techniques have the advantage of resorting on the deterministic trials that use the actual limit state function which is assessed for sampled values of the random variables, according to the respective probability distribution of each variable. Its disadvantage is that, very often, the number of required trials is too high and the method becomes time consuming.

Also, in order to explore the sensitivity of the results to the main variables, a parametric analysis is performed to assess the relative importance of the random variables. 
A graphical way to visualize the formulation is through a simplified flowchart as shown in Fig. 1.

En la fig. 1, modificar "FOSM" en vez de "FORM" y "First Order Second Moments" en vez de "First Order Reliability Methods"

Y en el cuadro de "Generation of trials for expected wave height (including epistemic uncertainty)" quitar "expected"

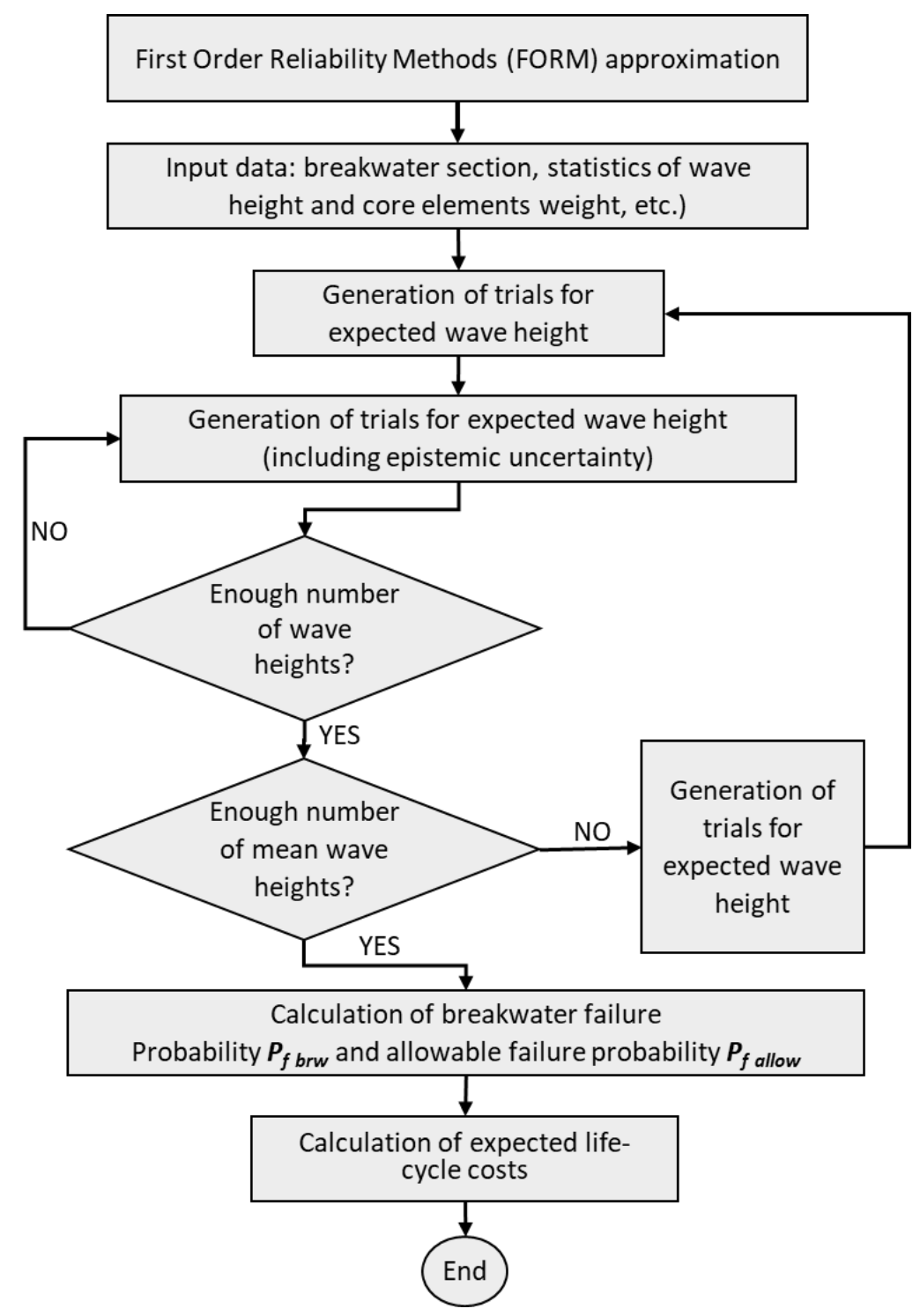

Fig. 1: Flowchart of the proposed procedure, where: $P_{f}=$ failure probability, $P_{f b r w}=$ failure probability of breakwater and $P_{\text {f allow }}=$ allowable (target) failure probability.

\subsection{First Order Second Moments (FOSM) approximation}


The stability of the breakwater core elements is considered to be the critical limit state function (LSF) and the actual weight of the core elements $\left(W_{c}\right)$ is compared to the design weight $\left(W_{d}\right)$.

$$
L S F=W_{c}-W_{d}
$$

Where $W_{c}$ may be taken as random, within the range of the specified weight in contracts' designs.

The design weight is taken from the Hudson formula (Hudson, 1959):

$$
W_{d}=\frac{\gamma_{s} H^{3}}{K_{d}\left(S_{s}-1\right)^{3} \operatorname{ctg} \theta}
$$

Where:

$\gamma_{s}=$ volumetric weight of the core element,

$K_{d}=$ constant of stability,

$\theta=$ inclination angle of breakwater profile, and

$S_{s}=$ specific volumetric density.

Given that the variability of the wave heigth $H$, in Eq. (2), is much higher (for the breakwater operational conditions) than the ones for the other parameters (which depend on design and materials properties), it is considered that the only random variable is $H$. The design weight, therefore, may be written:

$$
W_{d}=k H^{3}
$$

In the classical formulation of FOSM (Ang et al., 1984), the reliability index is expressed:

$$
\beta=\frac{E(L S F)}{\sigma_{L S F}}
$$

Where:

$$
E(L S F)=\left.L S F\right|_{E\left(W_{c}\right), E(H)}
$$

Or:

$$
E(L S F)=E\left(W_{c}\right)-k E^{3}(H)
$$

And, given that in this paper, the random variables are the wave height $H$ and the core element weight $W_{c}$, the variance of $L S F$ is:

$$
\sigma_{L S F}^{2}=\left.\frac{\partial E(L S F)^{2}}{\partial W_{c}}\right|_{E\left(W_{c}\right)} \sigma_{W_{c}}^{2}+\left.\frac{\partial E(L S F)^{2}}{\partial H}\right|_{E(H)} \sigma_{H}^{2}
$$




$$
\frac{\partial E(L S F)}{\partial W_{c}}=1
$$

And:

$$
\frac{\partial E(L S F)}{\partial H}=-3 k E^{2}(H)
$$

Therefore,

$$
\sigma_{L S F}^{2}=\sigma_{W_{c}}^{2}+\left[3 k E^{2}(H)\right]^{2} \sigma_{H}^{2}
$$

And:

$$
\beta=\frac{E\left(W_{c}\right)-k E^{3}(H)}{\sqrt{\sigma_{W_{c}}^{2}+\left[3 k E^{2}(H)\right]^{2} \sigma_{H}^{2}}}
$$

\subsection{Monte Carlo Simulation (MCS)}

The annual reliability index of the breakwater is calculated through MCS by including aleatory uncertainty on the mean wave height $E[H]$, and epistemic uncertainty in the wave height $(H)$ estimation, which is the design variable with the highest modeling uncertainty. It is assumed that this epistemic uncertainty may be represented by a positive factor, with lognormal variation. The median is $\lambda_{E[H]}$ and the dispersion measure is $\zeta=0.3$ :

$L N_{E[H]}\left(\lambda_{E(H)}, 0.3\right)$

The parameters of the lognormal distribution are (Ang et al., 2007):

$$
\begin{gathered}
\zeta=\sqrt{\ln \left(1+C V^{2}\right)} \\
\lambda_{E[H]}=\ln (E[H])-1 / 2 \zeta^{2}
\end{gathered}
$$

Where $E[H]$ and $C V$ are the mean and coefficient of variation of the wave heigth.

The calculation process is as follows:

1) Uniformly distributed values are generated in an Excel spreadsheet, and the lognormal mean wave height is obtained through the parameters $\lambda_{E(H)}$ and $\zeta$.

2) With the mean wave height and the lognormal parameters for the epistemic uncertainty, $\zeta=$ 0.3 , a new loop of simulation is performed, with the resulting wave height. 
3) The limit state $L S F$ is assessed and, at the end of the trials, it is counted how many times $L S F<0$. The failure probability is the ratio between the number of time $L S F<0$ and the total number of trials. The reliability index $\beta$ is calculated for each failure probability.

4) A histogram is built for all $\beta$ values and the mean value, and percentiles 75, 90 and 95 are located into the histogram.

\subsection{Expected life-cycle cost and target failure probability}

The expected life-cycle cost $E\left(L_{C}\right)$ is (Ang et al., 2005):

$$
E\left(L_{C}\right)=C_{i}+E(D C)
$$

Where:

$C_{i}=$ is the initial cost of the breakwater per unit length $=C_{1}-C_{2}\left[\ln \left(P_{f}\right)\right]$

$C_{l}$ and $C_{2}$ are constants that depend on the breakwater characteristics.

$P_{f}=$ failure probability.

$D C=$ Cost of damage/failure consequences, it includes the losses of commercial activities in the port.

$E(D C)=$ present value of the expected damage/failure cost $=(P V F) D C\left(P_{f}\right)$

The present value factor is expressed in terms of the net discount annual rate $r$ and the breakwater design lifetime $T$ :

$$
P V F=(1-\exp (-r T)) / r
$$

The minimization of expected life-cycle cost:

$$
\frac{\partial E(L C C)}{\partial p_{f}}=0
$$

Therefore, the target (allowable) annual failure probability is:

$$
P_{f}^{t}=\frac{C_{2}}{[(P V F)(D C)]}
$$

\section{Application to the breakwater in Lázaro Cárdenas port, México.}

\subsection{Industrial Lázaro Cárdenas port description}


The industrial and commercial Lázaro Cárdenas port is a leading international maritime access in the Mexican Pacific. The unbeatable position of Lázaro Cárdenas port favors access to the nations of the Pacific Basin and allows to participate in the most developed international shipping chains, it is strategically located along the main maritime trade routes of the pacific coast between Asia and America. Its geographical location is known as micro Balsas' delta production area, where a long port activity is developed, commercial and industrial activity takes place, with a tourist port only 45 minutes away. The Lázaro Cárdenas port is located in a strongly economic region, formed by the states of Michoacán, Guerrero, Querétaro, México, Morelos, and Ciudad de México. The 33\% of the total population of the country is located in this area and participates with $42 \%$ of the Gross Domestic Product in the national scope and with $49 \%$ of the manufacturing industry. The region has 31 thousand 581 kilometers of roads and 36 thousand 576 kilometers of railways. There are three international airports, the closest one is one hour far from Lazaro Cardenas Port, also there are three domestic airports, the nearest to the Port is only 15 minutes away. Additionally Lázaro Cárdenas port is considering the closest Mexican Pacific port to the center of the country (SCT, 2019a, 2019b).

The Lázaro Cárdenas port maintains a total coverage of more than 60 million inhabitants, concentrated in the most important economic zone nationwide covered by the states of Michoacán, Jalisco, San Luis Potosí, Morelos, Puebla, Veracruz, Tamaulipas, Querétaro, State of México, Guerrero, Guanajuato, Nuevo León, and Ciudad de México; area that creates more than $60 \%$ of GDP, states in which the majority of the production plants of the country are located, and with the highest demand for products of internal consumption. Its external influence is in the West Coast of North America with the United States and Canada, in Central America with Guatemala, El Salvador, Ecuador, Colombia, and Panama; in South America with Chile, Argentina, Peru, and in the Eastern Pacific Basin, such as Japan, Malaysia, the Philippines, Singapore, Taiwan, Korea, Russia, China, Taiwan, Indonesia, Thailand, Pakistan, New Zealand, South Africa, etc.

The Law on Ports was published in 1993, which rules the creation of Integral Port Administrations (API) so that these entities can promote the integral development of Mexican ports. Thus, the Lázaro Cárdenas API is responsible for building port infrastructure that guarantees private or public investments; monitors the productivity of the maneuvers and locates of the development areas to assure the settlement of new companies and terminals in the port (García, 2019).

The Lázaro Cárdenas port is one of the four ports that gets the largest percentage of commercial cargo movement in Mexico (without considering oil), which is a port area for the establishment of facilities and the provision of port services (attention to boats, as well as for the transfer of cargo, unloading and transshipment of merchandise), whose facilities are oriented to the attention of vessels of height 
and cabotage. Its modern facilities are equipped and qualified to cover with efficiency, safety and productivity all the activities of a high-level industrial and commercial port. The Lázaro Cárdenas port is the only port in Mexico with 18.00 meters depth in its access channel and 16.50 meters depth in the main dock of Ciaboga, sample of it, in March 22, 2019, "the Lázaro Cárdenas port received the largest ship that has ever docked in the history of the National Port System" (Cruz, 2018). The MSC Amsterdam ship with a capacity of 16,652 containers of 20 feet (TEU), which has a length of 399 meters and 54 meters of beam (Cruz, 2018). The docking capacity of the Lázaro Cárdenas port has 21,844 meters of water fronts, 3,689 meters of dock built with $6,8,11,12,14$, and 16.50 meters depth and with structural capacities to receive vessels of 20,000 to 150,000 tons of displacement (SCT, 2019a, 2019b); however it can receive vessels up to 165 thousand tons of displacement. Lázaro Cárdenas port has terminals for different cargo and special products: Grain terminal, agricultural bulk terminal and its derivatives, bulk mineral terminal and steel products, multipurpose terminal I, II and III, containers terminal I and 2, metals and minerals terminal, oil fluids terminal, coal terminal, fertilizers terminal, and dismantling of boats and handling of fluids terminal.

It is also considered the first automated port in Latin America, with the installation of Hutchison Ports Mexico and APM Terminals due to their use of advanced technology for container handling in the TEC II and TEC I terminals respectively, proof of this is Hutchison Ports Lázaro Cárdenas, who is considered the most efficient in the handling of containers in Mexico, Hutchison gives service to the motor carrier from his call to the transport regulatory center until he leaves the terminal with an import container with an average time of 33 minutes, having a productivity per ship of 110 containers unloaded per hour. Which made this terminal to be recognized internationally as the most efficient in Latin America in the container market (Cruz, 2018).

Based on information from the Instituto Mexicano del Transporte (IMT, 2019), the annual average growth rates of the containerized cargo in 2009-2015 period are: for the Pacific coastline $7.3 \%$ and for the Caribbean Gulf 6.6\%, distributed as follow based on the main port each zone: Lázaro Cárdenas growth $11.9 \%$, Manzanillo $6.8 \%$ and other ports of the Pacific 3.8\%, for the case of the Caribbean Gulf: Altamira 6.5\%, Veracruz 7.9\% and other Caribbean Gulf ports 3.1\%.

On the other hand, the expected results for the end of 2018 in terms of movement of containerized cargo through the ports of Mexico, show an important growth that places them above 6 million TEUs, an unprecedented figure in our country in which the Lázaro Cárdenas port is in second place with an amount 1 million 200 thousand TEU's, having an approximate growth of $12 \%$. The main products handled are those of the automotive industry, metals and minerals, fertilizers, cement, agricultural 
bulk and many others that are part of the international exchanges of Mexico with the world (García, 2019).

\subsection{River Balsas mouth hydraulic characteristics}

There are two breakwaters: north and south, their construction started in 1972 (south) and 1973 (north), they are 0.3 and 0.2 miles length respectively Fig. 2 shows the construction (API, 2009).

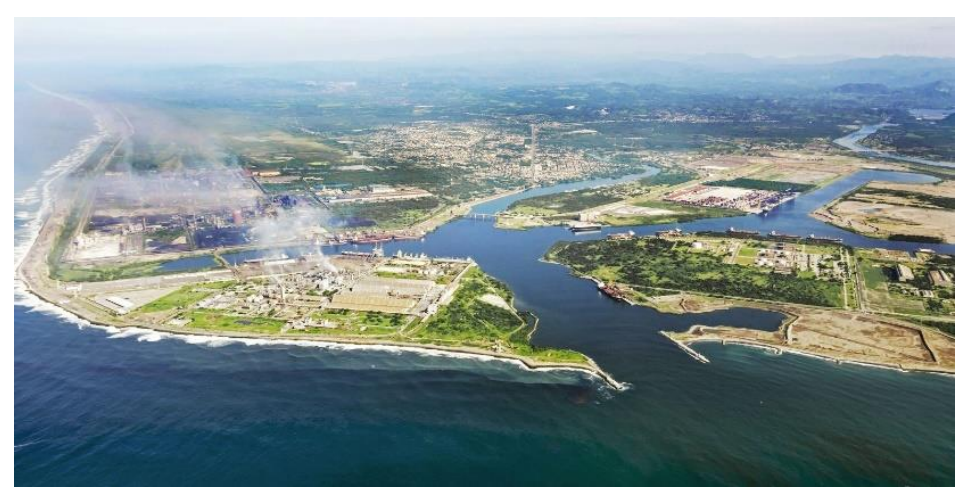

Fig. 2: Aerial view of Lázaro Cárdenas port.

The largest one, north one, is taken for this application, $6 \mathrm{~m}$ width structure with core protection elements at both sides. The purpose of this important infrastructure facility is to provide protection to the ships entering to the port by reducing the wave's energy. The cross section of the breakwater is shown in Fig. 3, crown width $=6 \mathrm{~m}$, crown height $=5 \mathrm{~m}$., slope 1 to 1.5 (SCT, 2001).

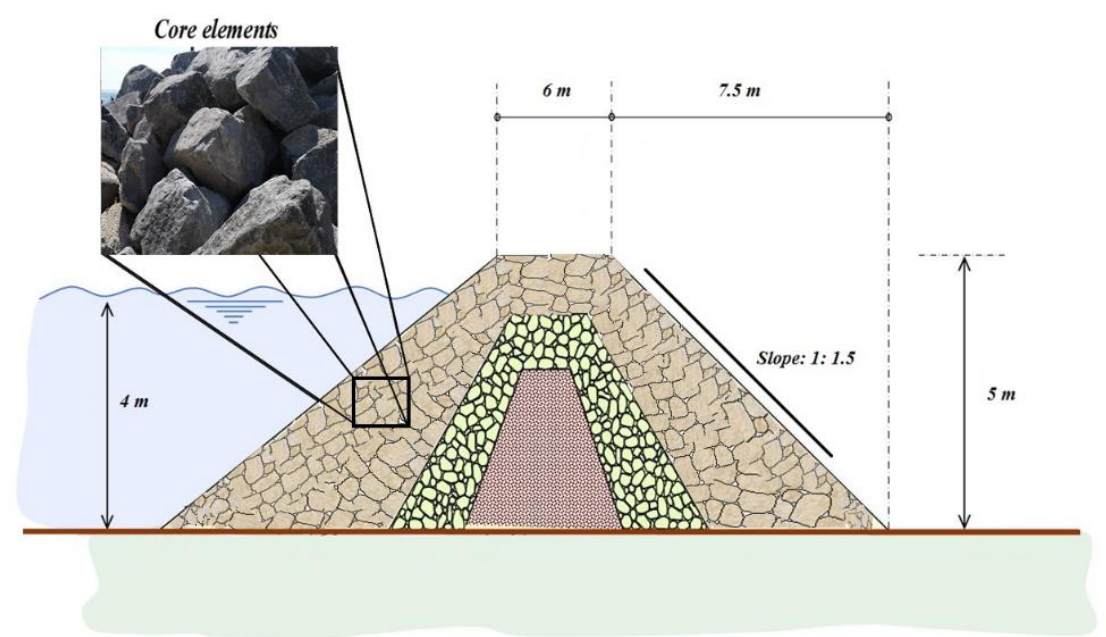


Fig. 3: Cross section of north breakwater at Lázaro Cárdenas port, information obtained from SCT (2001a, 2001b) and APILAC (2017)

Information for Lázaro Cárdenas from SCT (Secretaría de Comunicaciones y Transportes, 2001a, 2001b) and APILAC (Administración Portuaria Integral Lázaro Cárdenas S.A. de C.V., 2017).

\subsection{Quantitative application of proposed methods}

The stability of the breakwater of Lázaro Cárdenas port is calculated with the follow parameters (SCT, 2001b):

$\gamma_{s}=2.7 \mathrm{ton} / \mathrm{m}^{3}$,

$K_{d}=21.82$,

$\theta=$ slope 1.5 to $1(\operatorname{ctg} \theta=1.5)$

$S_{s}=$ specific volumetric density $=2.7$,

$W_{c}=$ range 4.5 to 5.5 tons

Given that in Eq. (2) the only random variable is $H$, the design weight may also be written:

$$
\begin{gathered}
W_{d}=k H^{3} \\
k=0.025
\end{gathered}
$$

Half-range of wave height: 0.5 to $10 \mathrm{~m}$ : this maximum was during the hurricane Patricia, (El Financiero, 2015).

Assuming a linear distribution, with maximum at $\mathrm{H}=0.5 \mathrm{~m}$ and 0 at $\mathrm{H}=10 \mathrm{~m}$, see appendix $\mathrm{A}$ :

Mean $=3.16 \mathrm{~m}$

$\sigma=2.28 \mathrm{~m}$

Lognormal parameters for wave height $\lambda=0.94, \zeta=0.64$,

LN $(0.94,0.64)$

Now, given that the core elements weight is random, in the range 4.5 to 5.5 tons (APILAC, 2017), and assuming a normal distribution, the half-range is taken as $3 \sigma$ and:

$3 \sigma=0.5$

$\sigma=($ Maximum-mean value $) / 3=0.167 \mathrm{~m}$ 
And:

$C V=0.033, \zeta=0.03$, and $\lambda=1.6$;

Then:

$$
\begin{gathered}
\sigma_{L S F}^{2}=\sigma_{W_{a}}^{2}+\left[0.025 E^{2}(H)\right]^{2} \sigma_{H}^{2} \\
\sigma_{L S F}=\sqrt{0.166^{2}+(3 * 0.025 * 3.16)^{2}(0.167)^{2}}=1.79
\end{gathered}
$$

Therefore, the reliability index is:

$$
\beta=\frac{E(L S F)}{\sigma_{L S F}}=2.34
$$

And the annual failure probability is:

$$
P_{f}=1-\emptyset(2.34)=9.6 \times 10^{-3}
$$

Given that $C_{2}$ is the cost of improving the breakwater safety, in an order of the natural log of failure probability, a curve of several initial costs is required to estimate the ordinate for that cycle reduction. As observed, the target failure probability $P_{f}^{t}$ depends mainly on the failure cost or the costs of failure consequences. By considering $r=0.1, T=100$ years and $C_{2}=0.15$ million USD, a plot is shown in Fig. 4. $C_{2}$ is calculated by estimating the weight of core elements that would be required to fit the reduction on failure probability in one order of magnitude (2.718):

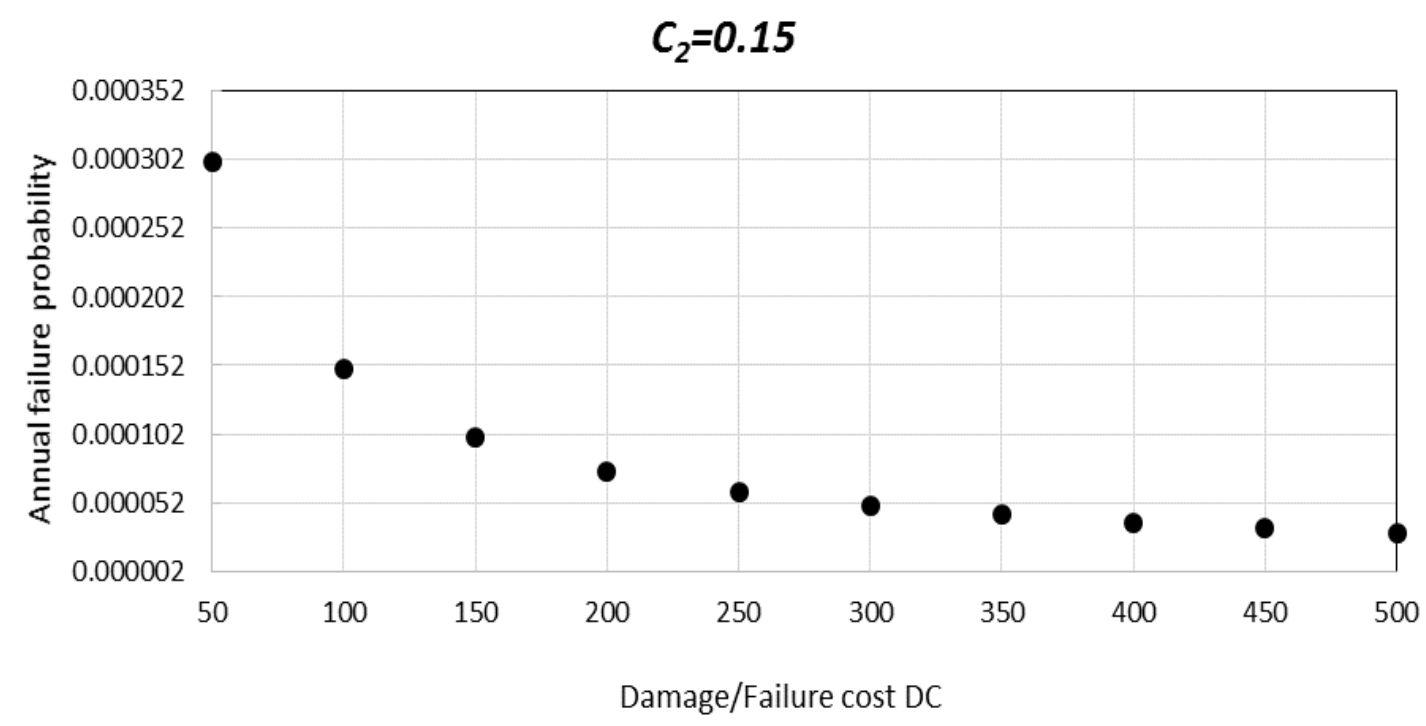

Fig. 4: Target failure probability as a function of the losses $(D C)$ 
The initial costs per unit length, of the breakwater, are built on the basis of conventional unit costs practices. The curve, for several reliability indices is shown in Fig. 5.

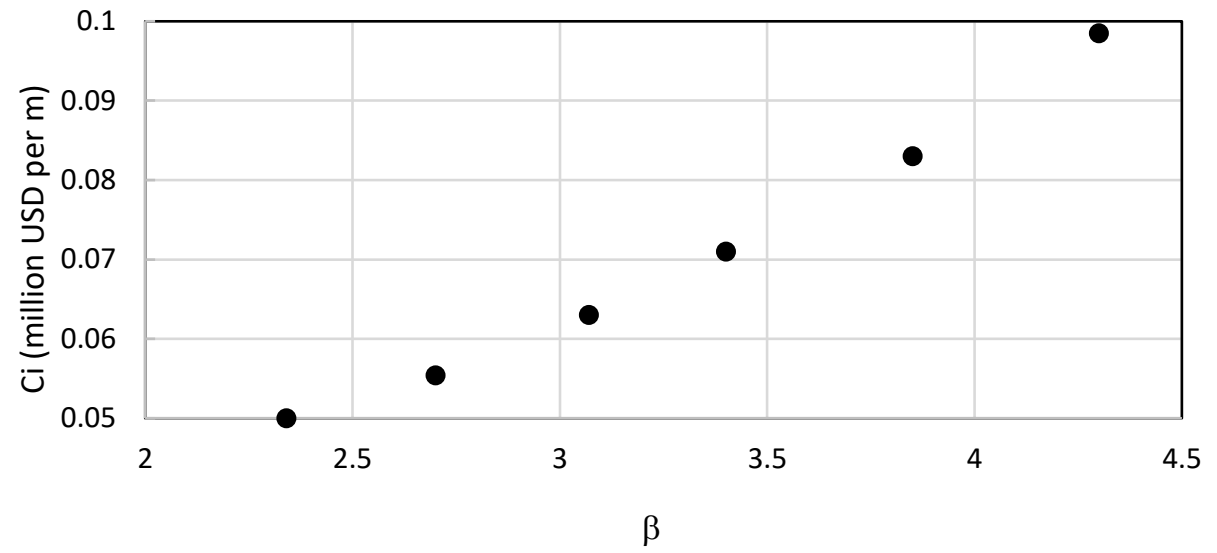

Fig. 5: Breakwater initial cost (in million USD per meter) versus annual reliability index.

If the wave height is lognormal (Ochi et al., 1980), the corresponding parameters are $\lambda_{E(H)}$ and $\zeta$.

For $E(H)=4.1 \mathrm{~m}$ for example,

$\lambda_{E(H)}=1.366$,

$\zeta=0.3$

$\operatorname{LN}(0.762,0.3)$

By applying MCS technique several times, a histogram of the breakwater reliability index is obtained. See Fig. 6 for the histogram of the reliability index, the mean value (3.7) and some characteristic percentiles: $80 \%$ is 3.9 and $95 \%$ is 4.3 . 


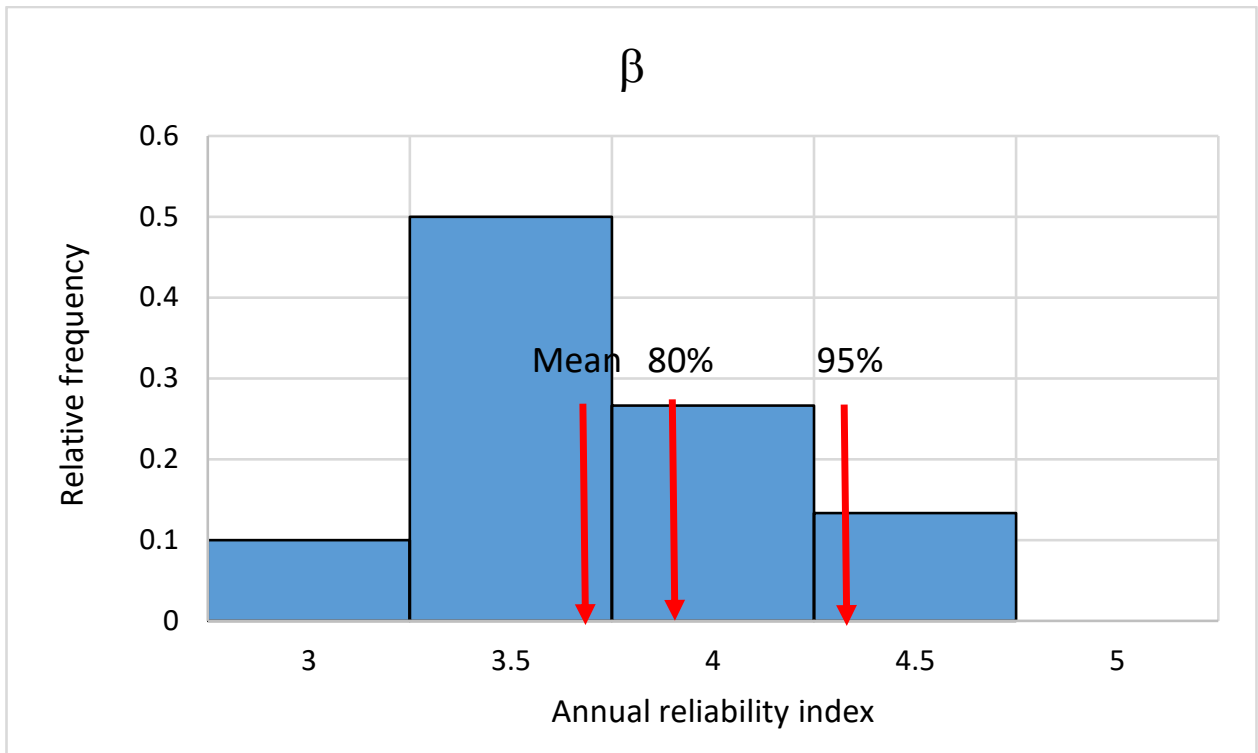

Fig. 6: Histogram for the annual reliability index with $\zeta=0.3$

\subsection{Failure consequences and implications on costs}

The consequences of breakwater failure include: the cost associated with potential fatalities, the loss of the breakwater and the loss produced for the breakdown or interruption of commercial port activities

The income reported by API Lázaro Cárdenas, it is detailed by management income, sales revenue, financial income, other income, and miscellaneous income from 2014 to 2017, is approximately a total of 10.5 thousand millions Mexican pesos (MXP), considering an annual average revenue of 2.6 thousand millions MXP (SCT-API, 2019). Based on García (2019) the Lázaro Cárdenas port for the year 2018 had a growth of approximately $12 \%$, this can be used to estimate an income of 2.9 thousand millions MXP, approximately 150 million USD, it directly impacts the economy of the country.

The costs related to fatalities and the cost of breakwater is considered to be 150 million USD and the cost of business interruption is also 150 million USD and the total failure cost is, therefore, 300 million USD. The main implication of the increment on the failure costs is the reduction on the target failure probability as revealed by the Fig. 2 where, for the cost of 300 million USD, the target failure probability is $5 \times 10^{-5}$.

\section{Analysis of results}


The FORM approximation is a simplified form to deal with the calculation of the reliability of complex systems; however, because of the consideration of only the linear terms on the Taylor series, the result underestimates the reliability index (2.34) as compared to the mean reliability index (3.7) calculated by the MCS procedure. And the reason of that is the highly nonlinear (cubic) participation of the wave height in the limit state function.

The mean reliability index obtained by MCS meets the target value and, as a consequence, no improvement works are needed regarding the structural safety of the breakwaters core elements.

The procedure by MCS allows for the consideration of percentiles, or confidence levels, for the reliability index. This may be interpreted as the opening of a space to make conservative decisions according to the risk aversion of managers or operators of the port navigation operations.

In case the port increases the operations and the value of income generated, the target failure probability may be further reduced and the need to reinforce the breakwaters may be raised as the failure costs become larger.

\section{Conclusions and recommendations}

A procedure to assess the influence that the epistemic uncertainty contained on the model used to predict the wave height, has over the breakwaters reliability. Also, the cost/benefit balance between the costs of failure consequences and the breakwatwr reliability is included through the expected lifecycle costs.

For the breakwater illustrated here, it is shown that there is a strong impact of the large income generated by the port operation, on making a more conservative design of the breakwater. Also, the reliability index (2.34) obtained from the FORM approximation is underestimated because of the linear approximation. However, by following the MCS techniques, the mean reliability index is 3.7 and the percentiles 80 or 95 are 3.9 and 4.3 , respectively.

The proposed procedure may be used to implement a risk management for operation, inspection and maintenance of breakeaters, showing that important infrastructure requires stronger and more detailed safety criteria, because of its impacts directly to the national economy.

\section{Acknowledgements}

Data from the breakwater were made available from Mexican Institutions (Dirección de Puertos, SCT) and this support is fully acknowledged (DGPMM, 2001). 
This work was partially supported of CONACYT (Consejo Nacional de Ciencia y Tecnología), through a postdoctoral stay granted to Lourdes Loza Hernández in Engineering Faculty of Universidad Autónoma del Estado de México, in Mexico.

\section{References}

Ang, H.S.A., \& De Leon, D. (2005). Modeling and analysis of uncertainties for risk-informed decisions in infrastructures engineering, Structure and Infrastructure Engineering, 1:1, 19-31, DOI: $10.1080 / 15732470412331289350$

Ang, H.S.A., \& Tang, W.H. (1984). Probability concepts in engineering planning and design. Vol. II-Risk, reliability and decisions. John Wiley and Sons. New York. ISBN-13:978-0471032014.

Ang, H.S.A., \& Tang, W.H. (2007). Probability concepts in engineering Emphasis on Applications to Civil and Environmental Engineering (v. 1), 2n. Edition. John Wiley and Sons. New York. ISBN13:978-0471720645.

API (Administración Portuaria Integral de Lázaro Cárdenas, 2009). Manifestación de impacto ambiental modalidad regional. Lloyd Germánico de México, $\mathrm{S}$ de R.L. de C.V. http://sinat.semarnat.gob.mx/dgiraDocs/documentos/mich/estudios/2009/16MI2009VD001.pdf

APILAC (Administración Portuario de Lázaro Cárdenas, S.A. de C.V., 2017). Junta de Aclaraciones de Licitación Púbica Nacional 09178002-023-17, 2017. Secretaría de Comunicaciones y Transportes, https://www.puertolazarocardenas.com.mx/plc25/documentos/licitaciones/CONVOCATORIAS/IN GENIERIA/conv_14/ACTA\%20_JA_LP_23_17.pdf

Burcharth, H. F. (1987). The Lessons from recent breakwater failures: developments in breakwater design. Paper presented at Technical Congress on Inshore Engineering, Vancouver, Canada.

Castillo E., Losada A., Mínguez R., Castillo C., \& Baquerizo A. (2004). Optimal engineering design method that combines safety factors and failure probabilities: Application to rubble-mound breakwaters. Journal of Waterway, Port, Coastal and Ocean Engineering, ASCE. 130(2):77-88.

Christian E., Burcharth H. F., \& Sorensen J. D. (1996). Reliability based optimal design of vertical breakwaters modelled as a series system of failure Chapter 124, Procs. of the $25^{\text {th }}$. Conference on Coastal engineering, Orlando, Fl. 
Cruz, P.O. (2018). Arriba a México el buque más grande en su historia. Magazine Grupo T21. http://t21.com.mx/maritimo/2019/03/22/arriba-mexico-buque-mas-grande-su-historia). Accessed Marzo 22, 2019.

Dai Viet, N., Verhagen, H.J., Van Gelder, P.H.A.J.M., \& Vrijling, J.K., (2008). Conceptual Design for the Breakwater System of the South of Doson Naval Base: Optimization versus Deterministic Design. In Proceedings of the PIANC-COPEDEC VII: 7th International Conference on Coastal and Port Engineering in Developing Countries. "Best Practices in the Coastal Environment", Dubai, United Arab Emirates, Paper No. 053. 24-28. February, 2008.

Der Kiureghian A., Ditlevsen O. Aleatory or epistemic? Does it matter? (2010) Structura Safety 31(2): 105-112.

DGPMM (Dirección General de Puertos y Marina Mercante, México, 2001) Manual de dimensionamiento portuario, Secretaría de Comunicaciones y Transportes, Capítulo 3, Condicionantes Físicas. (In Spanish).

El Financiero, 2015. https://www.elfinanciero.com.mx/nacional/por-que-el-huracan-patricia-es-elmas-peligroso-de-la-historia-de-mexico. Accesed in April 2019.

Esteva, L. (1969). Seismicity prediction: a Bayesian approach. Proceedings of the 4th World Conference on Earthquake Engineering, Santiago, Chile.

García, S. (Jan 3, 2019). Los puertos de México de cara al 2019. Magazine Aduanas. http://aduanasrevista.mx/los-puertos-de-mexico-de-cara-al-2019/. Accessed March, 2019.

Hudson, R.Y. (1959). Design of quarry-stone cover layers for rubber-mound breakwaters. WES Research Report 2-2. Vicksburg. 1959.

IMT (Instituto Mexicano de Transporte, 2019). Escenarios de Flujo de Carga en México con base en el modelo nacional de transporte. Moreno, Q., Bustos, R. A., Gradilla, L.A.H., Martner, C.P., Publicación Técnica No. 539 Sanfandila, Querétaro, 2019.

Jiang, C., Zheng J.and Han X. (2018) Probability interval hybrid uncertainty analysis for structures with both aleatory and epistemic uncertainties: a review. Structural and Multidisciplinary Optimization, 57(6): 2485-2502.

Koç M. L., \& Balas, C. E. (2013). Reliability analysis of a rubble mound breakwater using the theory of fuzzy random variables, Applied Ocean Research, Volume 39, January 2013, Pages 83-88, https://doi.org/10.1016/j.apor.2012.10.007 
Magoon, O. T., Sloan, R. L., \& Foote, G. L. (1974). Damages to Coastal Structures. Proceedings of the 14th International Coastal Engineering Conference, American Society of Civil Engineers, Vol 3, pp 1655-1676.

MarCom WG 196 (Committee from PIANC, 2016), Criteria for the Selection of Breakwater Types and their Related Optimum Safety Levels, Belgium.

Melby, J. A., \& Mlakar, P. F. (1997). Reliability assessment of breakwaters, Technical Report CHL97-9, U.S. Army Engineer Waterways Experiment Station, Vicksburg, MS.

Mimura, N., Yasuhara, K., Kawagoe, S., Yokoki, H., \& Kazama, S. (2011). Damage from the Great East Japan Earthquake and Tsunami - A quick report. Mitigation and Adaptation Strategies for Global Change, October 2011, Volume 16, Issue 7, pp 803-818, doi.org/10.1007/s11027-011-92977.

Mínguez, R., Castillo, E., Castillo, C., \& Losada, M.A. (2006). Optimal cost design with sensitivity analysis using decomposition techniques. Application to composite breakwaters. Structural Safety. 28, 321-340.

Nagao-Takashi, Moriya-Yoichi and Washio, T. (2005). Optimization of the target failure probabilities for port structures. IX ICASP. San Francisco, CA. 2005.

Ochi M. K and Whalen J. E., (1980). Prediction of the severest significant wave height, Coastal Engineering, pp. 587-599.

Oumeraci, H., Allsop, N.W.H., De Groot, M.B., Crouch, R.S., \& Vrijling, J.K. (1999). Proverbs: Probabilistic design tools for vertical breakwaters. Civil Engineering and Geosciences Faculty, Hydraulic Engineering Department. TU-Delft. http://resolver.tudelft.nl/uuid:ce9ec158-78b0-484a9344-d55c326b4ede

Sargent, F. E., Markle, D. G., \& Grace, P. J. (1988). Technical report remr-co-3 case histories of corps breakwater and jetty structures, Report 4 Pacific Ocean division by Coastal Engineering Research Center, Department of The Army Waterways Experiment Station, Corps of Engineers, Vicksburg, Mississippi.

SCT (Secretaría de Comunicaciones y Transportes, 2001a). Manual de dimensionamiento portuario. https://www.puertoensenada.com.mx/upl/sec/Manual_Dimensionamiento_Portuario.pdf

SCT (Secretaría de Comunicaciones y Transportes, 2001b). Listado de Puertos. Departamento De Catastro, Instalaciones y Recintos. Coordinación General de Puertos y Marina Mercante, Dirección General De Puertos, Dirección de Obras Marítimas y Dragado. 
http://www.sct.gob.mx/fileadmin/CGPMM/U_DGP/Catastro/assets/Documents/2001/Pacifico/Mich oacan/Lazaro_Cardenas/LazaroCardenas.pdf

SCT (Secretaría de Comunicaciones y Transportes, 2019a). Datos y recursos. Coordinación de Puertos y Marina Mercante. Administración Portuaria Integral de Lázaro Cárdenas. https://www.puertolazarocardenas.com.mx/plc25/servicios-portuarios/47-estadicas. Accessed in March, 2019.

SCT (Secretaría de Comunicaciones y Transportes, 2019b). Estadísticas. Coordinación de Puertos y Marina Mercante. Administración Portuaria Integral de Lázaro Cárdenas. https://www.puertolazarocardenas.com.mx/plc25/ml-servicios-portuarios/ml-estadisticas. Accessed in March, 2019.

SCT-API (Secretaría de Comunicaciones y Transportes-Administración Portuaria Integral de Lázaro Cárdenas, 2019). Datos abiertos, Estado de Actividades de Ingresos y Gastos -Resultados. https://www.puertolazarocardenas.com.mx/plc25/noticias/636-datos-abiertos. Accessed in April, 2019.

SEMAR (Secretaria de Marina, 2019). Puerto Lázaro Cárdenas, México. Dirección General Adjunta de Oceanografía, Hidrografía y Meteorología.

https://digaohm.semar.gob.mx/cuestionarios/cnarioLazaro.pdf. Accessed in March, 2019.

Sorensen, J.D., Burcharth, H.F., \& Christiani, E. (1994). Reliability analysis and optimal design of monolithic vertical wall breakwaters. Proc. 6th IFIP WG7.5 Assissi, Italy. Chapman \& Hall.

U.S. ARMY Corps of Engineers (1977). Shore Protection Manual. Published by Coastal Engineering Research Center, Kingman Building. Fort Belvoir, Virginia. 22060 USA.

Van de Kreeke, J., \& Paape, A. (1964). On Optimum Breakwater Design. In Proceedings of 9th Conference on Coastal Engineering, Lisbon, Portugal (pp. 532-552). New York, NY: American Society of Civil Engineers.

Van der Meer, J.W. (1988a). Rock slopes and gravel beaches under wave attack. Doctoral thesis, Delft University of Technology. Also Delft Hydraulics Publication no. 396.

Van der Meer, J.W. (1988b). Deterministic and probabilistic design of breakwater armour layers. Proc. ASCE, Journal of WPC and OE, Vol. 114, No. 1.

Volpe National Transportation Systems Center (1998). Value of Information and Information Services. U.S. Department of Transportation Research and Special Programs Administration. Publication No. FHWA-SA-99-038. 
Xiao N. C., Huang, H. Z., Wang, Z. L., et al. (2012) Unified uncertainty analysis by the mean value first order saddlepoint approximation. Structural and Multidisciplinary Optimization, 46(6): 803812. 


\section{APPENDIX A.}

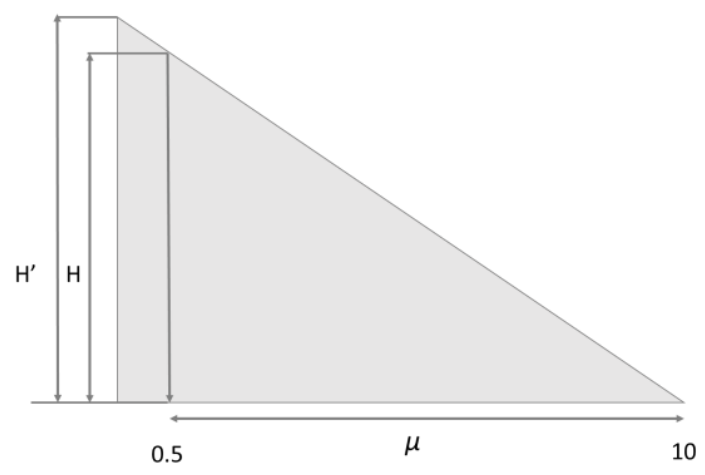

Fig. A.1: Graphic representation of linear distribution proposed.

Considering the parameters, $\mu$ is calculated by:

$$
\mu=\frac{9.5}{3}=3.17
$$

Random variable $H$ from:

$$
\begin{gathered}
\frac{9.5 H}{2}=1 \\
H=\frac{2}{9.5}=0.21
\end{gathered}
$$

To calculate $X$ and $H^{\prime}$ to determine the equation of the line:

$$
\begin{gathered}
X=0.21\left(\frac{0.5}{9.5}\right) \\
X=0.011 \\
H^{\prime}=H+X \\
H^{\prime}=0.221
\end{gathered}
$$

The equation of the line is given by:

$$
Y=-0.0221 X+0.221
$$

The variance of $L S F$ is calculate by:

$$
\sigma^{2}=\int_{0.5}^{10}(X-3.17)^{2}(-0.0221 X+0.221) d x
$$


Solving the integral:

$$
\begin{gathered}
\sigma^{2}=\int_{0.5}^{10}\left(X^{2}-6.34 X+10.05\right)(-0.0221 X+0.221) d x \\
\left.\sigma^{2}=\frac{-0.0221 X^{4}}{4}+\frac{0.361 X^{3}}{3}-\frac{1.622 X^{2}}{2}+2.22 X\right]_{0.5}^{10}
\end{gathered}
$$

Integral evaluation:

$$
\sigma^{2}=\frac{-221}{4}+\frac{0.0221}{64}+\frac{361}{3}-\frac{0.361}{24}-\frac{162.2}{2}+\frac{1.622}{8}+(2.22)(9.5)
$$

And,

$$
\begin{gathered}
\sigma^{2}=-55.25+120.3-0.015-81.1+0.2+21.09 \\
\sigma^{2}=141.59-136.37
\end{gathered}
$$

Therefore,

$$
\sigma=2.28
$$

